\title{
Salinity (sodium and potassium chloride) influence on germination and growth factors of wheat (Triticum aestivum)
}

\author{
Zubia Rahim ${ }^{1 *}$, Gulnaz Parveen ${ }^{1}$, Naila Mukhtar ${ }^{2}$ and Kiran Natasha ${ }^{3}$ \\ 1. Department of Botany, Women University, Swabi, Swabi-Pakistan \\ 2. Department of Botany, Government College University Faisalabad, Layyah Campus-Pakistan \\ 3. Qurtaba University of Information and Technology Peshawar Campus-Pakistan \\ *Corresponding author's email: zubia.rahim@wus.edu.pk
}

Citation

Zubia Rahim, Gulnaz Parveen, Naila Mukhtar and Kiran Natasha. Salinity (sodium and potassium chloride) influence on germination and growth factors of wheat (Triticum aestivum). Pure and Applied Biology. Vol. 8, Issue 3, pp20442050. http://dx.doi.org/10.19045/bspab.2019.80149

\begin{tabular}{llll}
\hline \hline Received: 03/05/2019 & Revised: 15/07/2019 & Accepted: 16/07/2019 & Online First: 25/07/2019 \\
\hline \hline
\end{tabular}

\section{Abstract}

The effects of salt stress on wheat (Triticum aestivum) was assessed by application of various concentrations $(100,150,200$ and $250 \mathrm{mM})$ of two types of salts $(\mathrm{NaCl}, \mathrm{KCl}$ and Mixture of $\mathrm{NaCl}$ and $\mathrm{KCl}$ ). This study revealed the extent to which the Wheat plant can tolerate the salt stress. The germination and growth parameters were analyzed in laboratory and in pots by application of the said concentrations of salts. Increasing levels of the salts reduced the growth of Wheat (Triticum aestivum) plant. Radical length reduced to $0.5,0.3$ and $0.2 \mathrm{~cm}$ at $200 \mathrm{mM}$ concentrations of $\mathrm{NaCl}$, $\mathrm{KCl}$ and mixture of $\mathrm{NaCl}$ and $\mathrm{KCl}$ respectively which is less than control $(2.8 \mathrm{~cm})$. The stem length, leaves length, stem breadth, number of tillers, number of leaves per plant, number of seeds per spike, spike length, weight of whole plant and weight of 50 grains of wheat showed reduction as the salinity levels increased to $200 \mathrm{mM}$ and $250 \mathrm{mM}$ compared to control. Wheat plant is found to be salt sensitive plant, not suggested to grow in saline or waterlogged areas.

Keywords: Cereal; Crop; Concentration; Mixture; Salt; Stress

\section{Introduction}

In this era of rising urbanization and development our diets are in transition states of being replaced by the food with refined fats, refined sugars and many other artificial ingredients [1], but cereal grains are major part of human diet for decades [2] because it provides more energy worldwide [3]. Universally cereals are significant food crops [3-5]. Billions of people depend majorly upon wheat, rice and maize and slightly on millet and sorghum $[2,6]$, among them wheat stand second after maize [4], while millet is sixth most exclusive of them [7]. Cereal grains provide $50 \%$ of world's caloric need [2]. Crude cereals are rich in carbohydrates majorly starch (65 to 75\%), vitamins, proteins (6 to $12 \%$ ), minerals, oils and fats (1 to $5 \%$ ). These cereals are suggested for chief part of food because of their high fiber content which checks weight gain and cardiac diseases $[3,8]$.

For agricultural production, Irrigation of the land with salinity is one of the major environmental issue [9] and it's a major menace to modern agriculture resulting in impairment and imbalance in development of crop growth [10]. Due to salinization, 
different anthropogenic activities also in turn affects the processes of irrigation [11]. Salinity is the major issue of semi-arid and arid regions and now it has been debated as a worldwide environmental issue $[12,13]$ Attempts have been made to discover the phenomenon of promoting salinity tolerance among different crops either by approaches related to molecular biology or with the help of salt tolerant genes transfer [14,15]. Sodium chloride has numerous functions in cereals, but its decrease is a topic that should be concentrated on due to nutritious recommendations [16].

The yield of cereal crops especially rice has been noticed to be decreased due to certain factors along with salinity [17]. Rising levels of sodium chloride has negative impacts on wheat (Triticum aestivum) varieties [18]. Because salt stress is a type of ionic stress in which high chloride contents are accumulated in plants significantly which ultimately inhibits the uptake of potassium and other mineral ions [19] and among the ionic stress sodium is most hazardous ion which impairs the growth of plants by restricting their metabolic processes [20]. In many cases leaf area or shoot area of wheat (Triticum aestivum) does not show potentials to analyze the grain yield. whereas the gas exchange parameters can be correlated with biomass accumulation. The data reveals that stomatal closure is the main cause behind decrease in biomass production which may be due to inhibition of uptake of Potassium ion [21].

In the present scenario this experiment was conducted to check the salinity level and the vigor of Wheat (Triticum aestivum) plant to tolerate salt stress of various concentrations.

\section{Materials and methods}

\section{In-vitro test}

Wheat (T. astivum) Var. Atta Habib seeds were collected from department of botany Islamia College Peshawar, surface sterilized for 30seconds by Mercuric Chloride $\left(\mathrm{HgCl}_{2}\right)$
$(0.1 \%)$ and then washed by tap water, followed by distilled water. To find out the germination, plumule and radical length, seeds were placed in petri plates, already comprising a thin layer of cotton, and blotting paper. Petri dishes were sterilized and finally the seeds were soaked in salt solution $(10 \mathrm{ml})$ of various concentrations $(100,150,200$ and $250 \mathrm{~mm})$ of $\mathrm{NaCl}, \mathrm{KCl}$ and combined $(\mathrm{NaCl}+\mathrm{KCl})$. Each of the three replicates contained 5 seeds. Plates moistened with distilled water were considered as control. Petri dishes were incubated at $27{ }^{\circ} \mathrm{C}$ for 3 to 5days.

\section{In-vivo test}

\section{Soil used for experiment}

Sandy loam soil with $\mathrm{pH} 8.0$ taken from a trial field of the botanical garden, department of botany, Islamia College Peshawar, Pakistan was sterilized and used for cultivation of wheat.

\section{Pot experiment}

A pot experiment was performed in the screen house of the Islamia College Peshawar in completely randomized block design. Seeds of wheat (T. aestivum) were sown in $32 \mathrm{~cm}$ diameter Pots. Each containing $4 \mathrm{~kg}$ soil. 10 seeds of wheat (T.aestivum) were sown in pots. The pots were arranged randomized on a screen house bench. After germination of seeds, five seedlings were removed from each pot while 5 were left. When seedlings were at two leaf stage, saline solution $(100,150,200$ and $250 \mathrm{~mm})$ of $\mathrm{NaCl}$, $\mathrm{KCl}$ and combined $(\mathrm{NaCl}+\mathrm{KCl})$ were added to each pot after interval of 15 days. Various growth parameters included weight of whole plant, number of tillers, stem breadth, stem length, leaves length, number of leaves, number of seeds per spike, spike length, weight of 50 seeds of spike in each concentration and control were recorded after 90 days.

\section{Statistical analysis}


The experiment was performed and data was recorded by analysis of variance (ANOVA). For Germination and growth parameters of Wheat plant, data was subjected to one-way ANOVA followed by the least significant difference LSD test at $\mathrm{P}=0.05$. All analysis was performed using IBM-SPSS STATISTICS program [22].

\section{Results}

\section{In-vitro test}

Length of radicle and Plumule of wheat was significant $(\mathrm{p}<0.05)$ effected or decreased by increase of the salt stress compared to control. Maximum stress was observed in the length of radical and Plumule at maximum concentration $(200 \mathrm{mM})$ of salt solution i.e. mix salt $(\mathrm{NaCl}+\mathrm{KCl})$. Where it showed the minimum length like 1.1 and $0.2 \mathrm{~cm}$ respectively. Highly significant $(\mathrm{p}<0.05)$ effect of stress was observed at $100 \mathrm{mM}$ of salts solution when combine salts $(\mathrm{NaCl}+\mathrm{KCl})$ were used for germination percent (Table 1).

\section{In-vivo test}

Vegetative growth is highly stunted due to salt stress. Stem Length, Stem breadth, Number of tillers and number of leaves reduced at the most concentrated level $(250 \mathrm{mM})$ of $\mathrm{NaCl}, \mathrm{KCl}$ and mixture salt compared to control. The combine effect $(\mathrm{NaCl}+\mathrm{KCl})$ was observed to be more stress inducer. Length of leaves showed reduction at $200 \mathrm{mM}$ of mixture salt (i.e. $3.8 \mathrm{~cm}$ ) as compared to control (Figure 1).

$\mathrm{NaCl}$ is observed to reduce Spike length (1.9 $\mathrm{cm})$ and weight of whole plant $(0.12 \mathrm{~cm})$ at $250 \mathrm{mM}$ as compared to other concentrations and control i.e, $6.3 \mathrm{~cm}$ and 0.86 respectively. $\mathrm{KCl}$ imposed more stress on Number of seeds per spike $(4.3 \mathrm{~cm})$ at $250 \mathrm{mM}$ as compared to other salts and their concentrations and control $(20.7 \mathrm{~cm})$.

The yield of stressed crop also showed similar response like vegetative phase. Weight of 50 grains reduced at highly concentrated salt solution $(250 \mathrm{mM})$ of $\mathrm{mix}$ salt i.e. $1.5 \mathrm{~cm}$ as compared to other salt concentrations and control $(2.5 \mathrm{~cm})$ (Figure 2).

\section{Discussion}

Salinity highly affects growth and germination of Wheat as the concentrations of the salts $(\mathrm{NaCl}, \mathrm{KCl}$ and $\mathrm{NaCl}+\mathrm{KCl})$ increased. A significant reduction in length of root and shoot is reported at high concentration of $\mathrm{NaCl}$ by [23]. This reduction in root and shoot length may be caused by either toxic effects of $\mathrm{NaCl}$ higher concentrations or due to improper uptake of nutrients by seedlings. Higher levels of salinity may check the growth because of slow uptake of water for maintaining osmotic potential of plant under saline stress [23]. Germination percentage is reduced to $0.4 \mathrm{~cm}$ at $100 \mathrm{mM}$ concentration of mix salt solution which is also reported by [24].

According to [25] the concentrations at $125 \mathrm{mM}$ and $150 \mathrm{mM}$ of $\mathrm{NaCl}$ completely inhibited the Wheat (Triticum aestivum) varieties growth. The processes of growth are highly susceptible to the salt stress, which can be predicted by the biomass and production of the standing wheat (Triticum aestivum) crop. The yield reflects the capacity of the plant to tolerate the salt stress. The result indicated reduction in the weight of whole plant by application of salt stress as compared to control. Same result is indicated by [23]. According to them the weight of whole plant reduced by increase of $\mathrm{NaCl}$ concentrations.

Number of spikes per plant (NSP), Spike length (SL), Number of leaves per plant (NLP) decreased by increase of salt concentrations. The values of LSD show significance level for weight of 50 grains. The weight of grains reduced to $1.4 \mathrm{~cm}$ at $100 \mathrm{mM} \mathrm{NaCl}$ solution as compared to control. LSD show high significance level for number of tillers per plant as the concentration of salt solutions enhanced as compared to control. [26] worked on the 
same parameters i.e, NSP, SL, NLP, WTG (Weight of thousand grains) and NT of wheat
(Triticum aestivum) reduced by increase of levels of salt solution.
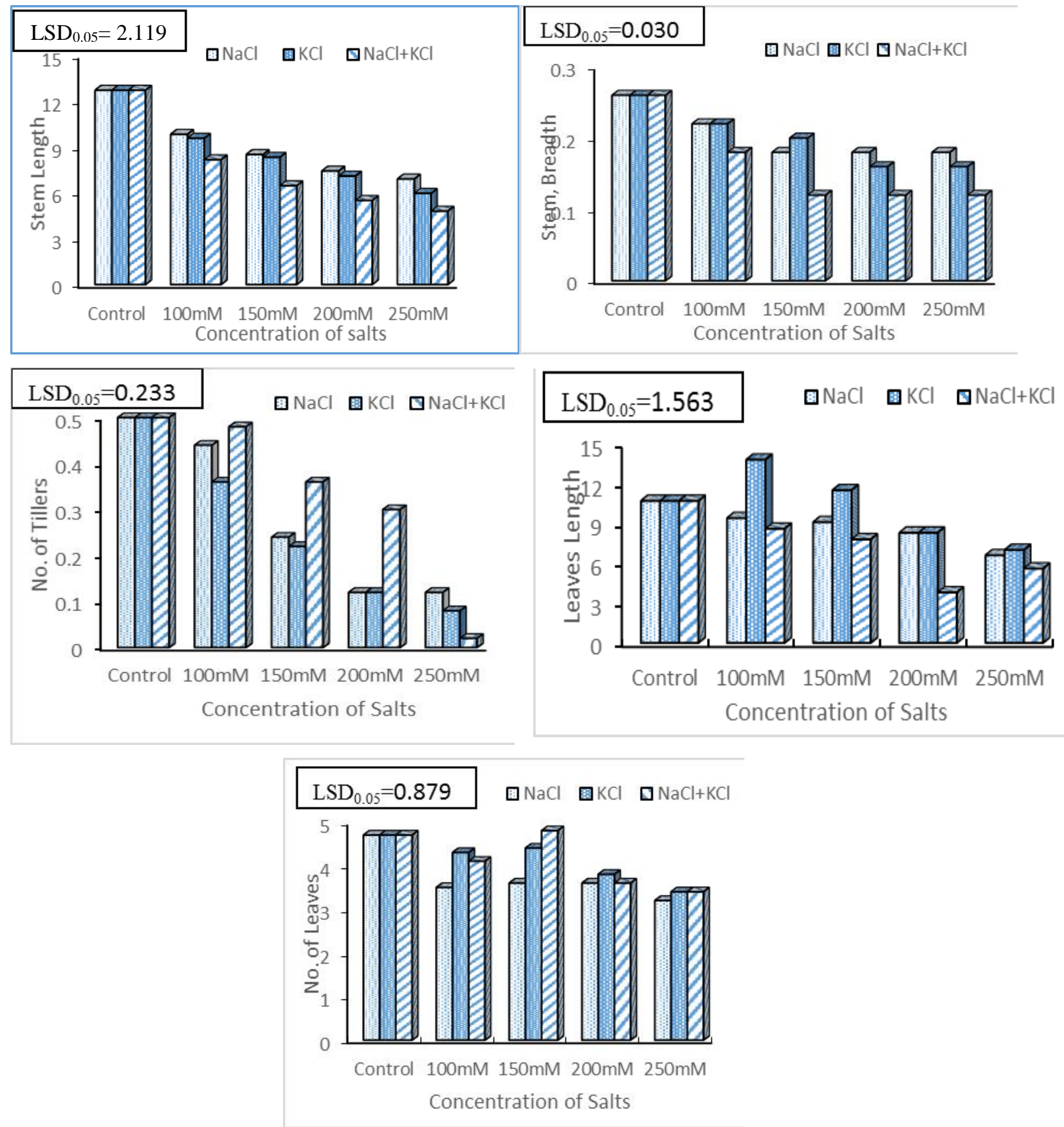

Figure 1. Effect of different salt concentrations $(100 \mathrm{mM}, 150 \mathrm{mM}, 200 \mathrm{mM}, 250 \mathrm{mM})$ on vegetative gowth of Wheat (Triticum aestivum) (Stem Length, Stem breadth, No. of Tillers, Leaves length and No. of Leaves) 

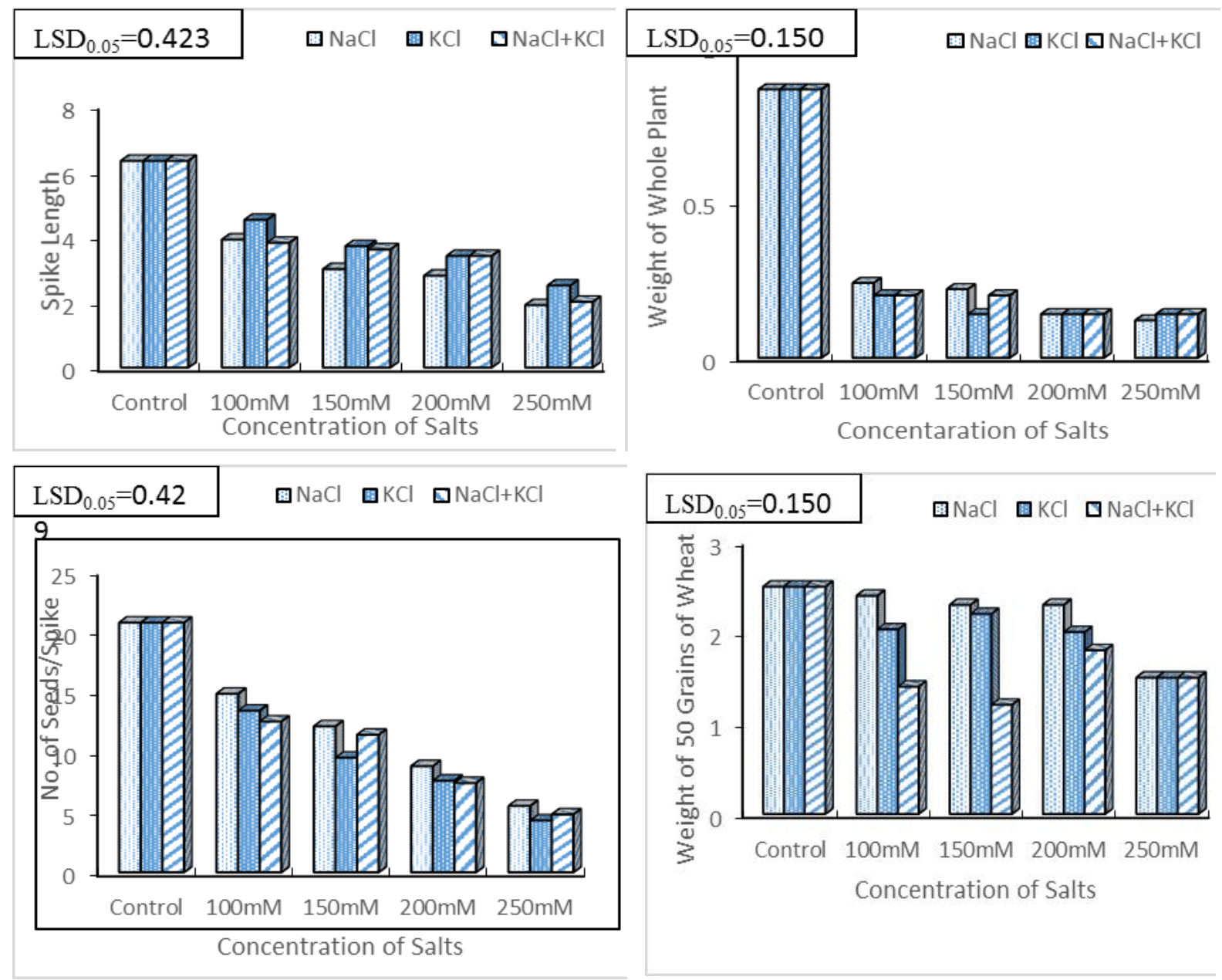

Figure 2. Effect of different salt concentrations (100 mM, $150 \mathrm{mM}, 200 \mathrm{mM}, 250 \mathrm{mM})$ on yield of Wheat (Spike Length, Weight of whole plant, Number of seeds per spike, weight of grains)

Table 1. Effect of different salt concentrations (100 mM, $150 \mathrm{mM}, 200 \mathrm{mM}, 250 \mathrm{mM})$ on germination of Wheat

\begin{tabular}{|c|c|c|c|c|}
\hline Treatments & Concentration & $\begin{array}{c}\text { Radical Length } \\
(\mathbf{c m})\end{array}$ & $\begin{array}{c}\text { Plumule Length } \\
(\mathbf{c m})\end{array}$ & $\begin{array}{c}\text { Germination\% } \\
(\mathbf{c m})\end{array}$ \\
\hline Control & Distilled Water & 2.8 & 3 & 1 \\
\hline \multirow{3}{*}{$\mathbf{N a C l}$} & $100 \mathrm{mM}$ & 2.6 & 1.5 & 0.9 \\
\cline { 2 - 5 } & $150 \mathrm{mM}$ & 2.3 & 0.5 & 0.6 \\
\cline { 2 - 5 } & $200 \mathrm{mM}$ & 2.0 & 0.5 & 0.6 \\
\hline \multirow{3}{*}{ KCl } & $100 \mathrm{mM}$ & 2.1 & 1.04 & 0.9 \\
\cline { 2 - 5 } & $150 \mathrm{mM}$ & 2.2 & 0.4 & 0.6 \\
\cline { 2 - 5 } & $200 \mathrm{mM}$ & 1.7 & 0.3 & 0.6 \\
\hline \multirow{3}{*}{$\mathbf{N a C l}+\mathbf{K C l}$} & $100 \mathrm{mM}$ & 2.1 & 0.9 & 0.4 \\
\cline { 2 - 5 } & $150 \mathrm{mM}$ & 2.1 & 0.3 & 0.5 \\
\cline { 2 - 5 } & $200 \mathrm{mM}$ & 1.1 & 0.2 & 0.054 \\
\hline \multicolumn{2}{|c|}{ LSD0.05 } & 0.101 & 0.053 & \\
\hline
\end{tabular}




\section{Conclusion}

It is concluded that increase of salt concentrations highly affected the growth and germination of wheat (Triticum aestivum). Among all concentrations $200 \mathrm{mM}$ and $250 \mathrm{mM}$ levels caused more stress. The yield of wheat was reduced highly by increase of salt concentrations. Further research need to be done to developed the resistant or salinity tolerance of wheat (Triticum aestivum) variety to overcome the losses of wheat in saline area and ultimately enhance the economy of Pakistan.

\section{Authors' contributions}

Conceived and designed the experiments: $\mathrm{Z}$ Rahim, Performed the experiments: Z Rahim, Analyzed the data: G Parveen \& Z Rahim, Contributed materials/ analysis/ tools: Z Rahim \& K Natasha, Wrote the paper: G Parveen, Z Rahim \& N Mukhtar.

\section{References}

1. Tilman D \& Clark M (2014). Global diets link environmental sustainability and human health. Nature 515: 518-522.

2. Awika JM (2011). Major cereal grains production and use around the world. Soil \& Crop Science Dept/Nutrition and Food Science Dept 1089: 1-13.

3. Sarwar MH, Sarwar MF, Sarwar M, Qadri NA \& Moghal S (2013). The importance of cereals (Poaceae: Gramineae) nutrition in human health: $A$ review J Ceraels Oil Seeds 4(3): 32-35.

4. Rubio-Casal AE, Castillo JM, Luque CJ, Figueroa ME (2003). Influence of salinity on germination and seeds viability of two primary colonizers of Mediterranean salt pans. $J$ of Arid Environ 53: 145-154.

5. Siddig A, Ali M, Adam KI, Babar AH \& Hassan TA (2013). Effect of sowing date and variety on growth and yield of pearl millet (Pennisetum glaucum L.) grown on two soil types under rain-fed condition at Zalingei area in Sudan. $J$ Sci Technol 3(4): 340-344.
6. Khush GS (2013). Strategies for increasing the yield potential of cereals: case of rice as an example. Plant Breed 132(5): 433-436.

7. Shahidi F \& Chanrasekara A (2013). Millet grain phenolics and their role in disease risk reduction and health promotion: A Rev J Func Food 5(2): 570-581.

8. Lafiandra D, Riccardi G \& Shewry PR (2014). Improving cereal grain carbohydrates for diet and health. $J$. Cereal Sci 59(3): 312-326.

9. Sreenivasulu N, Grimm B, Wobus U \& Weschke W (2000). Differential response of antioxidant compounds to salinity stress in salt-tolerant and saltsensitive seedlings of foxtail millet (Setaria italica). Physiol Plant 109: 435-442.

10. Isayenkov SV \& Maathuis FJM (2019). Plant Salinity Stress: Many Unanswered Questions Remain. Front. Plant Sci 10(80):1-11.

11. Florke M, Barlund I, Vliet MTH, Bouwman AF \& Wada Y (2019). Analysing trade-offs between SDGs related towater quality using salinity as a marker. Curr Opi Env Sus 36: 96-104.

12. Butcher K, Wick AF, DeSutter T, Chatterjee A \& Harmon J (2016). Soil salinity: a threat to global food security. Agron J 108: 2189-2200.

13. Daliakopoulos IN, Tsanis IK, Koutroulis A, Kourgialas NN, Varouchakis AE, Karatzas GP \& Ritsema CJ (2016). The threat of soil salinity: a European scale review. Sci Total Env 573: 727-739.

14. Purty RS, Kumar G, Singla-Pareek SL \& Pareek A (2008). Towards salinity tolerance in Brassica: An overview. Physiol Mol Biol Plants 14: 39-49.

15. Visarada KBRS, Meena K, Aruna C, Srujana S, Saikishore N \& Seetharama $N$ (2009). Transgenic breeding: 
Perspectives and prospects. Crop Sci 49: 1555-1563.

16. Reibner AM, Wendt J, Zahn S \& Rohm H (2019). Sodium-chloride reduction by substitution with potassium, calcium and magnesium salts in wheat bread. LWT 108: 153-159.

17. Fahad S, Adnan M, Noor M, Arif M, Alam M, Khan IA, Ullah H, Wahid F, Mian IA, Jamal Y, Basir A, Hassan A, Saud S, Amanullah M, Riaz K, Wu C, Khan MA \& Wang D (2019). In: Major constraints for global rice production. Adv Rice Res Abiotic Stress Tol 1-22.

18. Afridi MS, Amna T, Sumaira A, Mahmood T, Salam S, Mukhtar JA, Mahmood Z, Khatoon M, Bibi MT, Javed T, Sultan S \& Chaudhary HJ (2019). Induction of tolerance to salinity in wheat genotypes by plant growth promoting endophytes: Involvement of ACC deaminase and antioxidant enzymes. Plant Physiol. Biochem., In Press.

19. James RA, Blake C, Byrt SC \& Munns $R$ (2011). Major genes for $\mathrm{Na}+$ exclusion, Nax1 and Nax2 (wheat HKT1; 4 and HKT1; 5), decrease Na+ accumulation in bread wheat leaves under saline and waterlogged conditions. J Exp Bot 62: 2939-2947.

20. Wakeel A (2013). Potassium-sodium interactions in soil and plant under saline-sodic conditions. J Plant Nutr Soil Sci 176: 344-354.

21. Paul K, Pauk J, kondic-Spoka A, Grausgruber H, Allahverdiyev T, Sass L \& Vass I (2019). Co-occurrence of mild salinity and drought synergistically enhances biomass and grain retardation in wheat. Front Plant Sci doi: 10.3389/fpls.2019.00501.

22. Sokal RR \& Rohlf FJ (1995). Biometry: the principles and practice of statistics in biological research. $2^{\text {nd }} \mathrm{Ed}$. Freeman Publishers.

23. Datta JK, 1nag S, Banerjee A, \& Mondal NK (2009). Impact of salt stress on five varieties of Wheat (Triticum aestivum L.) cultivars under laboratory condition. J Appl Sci Environ Manage 13(3): 93-97.

24. Hadi MR, Khavarinejad RA \& KhoshKholgh S (2007). NaCl Effects on Accumulation of Minerals $(\mathrm{Na}+, \mathrm{K}+, \mathrm{Cl})$ and Proline in Triticum turgidum $\mathrm{L}$. Asian J of Plant Sci 6: 423-426.

25. Amor NB, Hamed KB, Debez A, Grignon C, Crabbedly (2005). Physiological and antioxidant responses of perennial halophyte Crithmum maritimum to salinity. Plant Sci 4: 889899.

26. Asgaria HR, Cornelisb W, Van \& Dam $P$ (2012). Salt stress effect on wheat (Triticum aestivum L.) growth and leaf ion concentrations. Inter $J$ of Plant Prod $6(2)$. 